\title{
Etanolia korsibiomassoista: Prosessi ja kannattavuus lopputuotteen kannalta
}

Niklas von Weymarn ${ }^{1)}$ ja Eemeli Hytönen ${ }^{2)}$

${ }^{1)}$ VTT, PL 100,02044VTT, niklas.weymarn@vtt.fi

${ }^{2)}$ VTT, PL 1603, 40101 Jyväskylä, eemeli.hytonen@vtt.fi

\section{Tiivistelmä}

VTT:n ja MTT:n yhteisessä kaksivuotisessa projektissa tutkittiin kotimaisten korsibiomassojen soveltuvuutta etanolivalmistuksen raaka-aineina. Tutkimuksessa perehdyttiin eritoten olkeen ja ruokohelpeen. Teknologia korsibiomassojen muuttamiseksi etanoliksi on olemassa. Laboratorio-olosuhteissa päästiin etanolisaannoissa raaka-aineesta hyvin lähelle arvioituja maksimiarvoja. Toisaalta, kun siirryttiin kohti teollisuudessa todennäköisesti käytettäviä olosuhteita (korkeampi kuiva-ainepitoisuus, vähemmän entsyymejä, runsaasti inhibiittoreita, jne.) maksimiarvoista jäätiin hieman. Näitä "teollisia" tuloksia käytettiin tehtyjen laskelmien lähtötietona.

Kriittiseksi tekijäksi muodostui biomassan saatavuus Suomessa. Arviomme mukaan raaka-aineita, olkea ja ruokohelpeä, saisi Suomesta parhaimmillaan kerättyä, 50 km keskisäteellä tehtaalta, noin 160000 tonnia vuodessa (kuivapaino). Tästä nykytekniikalla voisi tuottaa noin 31000 tonnia etanolia, eli tehdas olisi maailmalla suunniteltuihin tehtaisiin verrattuna hyvin pieni. Olki ja ruokohelpi olisi myös erikseen kerättävä ja kuljetettava tehtaalle. Tämä nostaa raaka-ainehintaa.

Laitoksen investointimenoksi arvioitiin noin 110 miljoonaa euroa. Tämä olisi selvästi enemmän kuin mitä vastaavankokoinen jyvää raaka-aineena käyttävä etanolitehdas maksaisi. Tuotantokuluiksi arvioitiin noin $1 € /$ litra tuotettua etanolia. Suurimmat kustannustekijät olivat investoinnin kuoletus, pääraaka-aineen hinta ja entsyymien valmistukseen liittyvät kulut. Etanolin myyntihinta EU:ssa on viimeisen vuoden aikana liikkunut 0,55..0,65 €/litra välillä. On siis selvää että käytetyillä lähtöravoilla tehdasinvestointi ei olisi kannattava.

Prosessikonsepteja ja teknologiaa kehittämällä selluloosapohjaisen etanolituoton kannattavuus on todennäköisesti kuitenkin mahdollista saavuttaa. Jatkokehitystyön keskeisempiä suuntaviivoja ovat i) toisenlaisten prosessikonseptien löytäminen, ii) entsyymikulujen alentaminen tai vaihtoehtoisten hydrolyysiratkaisujen kehittäminen, iii) etanolisaannon parantaminen, iv) investointimenojen alentaminen ja/tai v) arvokkaampien sivutuotteiden identifiointi.

Avainsanat: olki, ruokohelpi, etanoli, kannattavuus 


\section{Johdanto}

Etanolin ja muiden tieliikennebiopolttoaineiden kysyntä on kovassa kasvussa. Kansainvälinen energiajärjestö IEA arvioi vuoden 2005 kokonaistuotoksi vajaat 20 miljoonaa öljyekvivalenttitonnia (Mtoe), mistä noin $85 \%$ oli bioetanolia (Anon., 2006). Samaisen raportin varovaisempi tulevaisuuden arvio ennustaa tieliikennebiopolttoainetuotannon kasvavan vuoteen 2015 mennessä 54 miljoonaan öljyekvivalenttitonniin. Tämä määrä vastaisi kuitenkin vain noin $4 \%$ :a tieliikenteen kokonaispolttoainekulutuksesta vuonna 2015.

Johtavia tieliikennebiopolttoaineiden tuottajamaita, volyymeinä mitattuna, ovat Brasilia (v. 2005 8,2 Mtoe) ja Yhdysvallat (7,7 Mtoe) (Anon., 2006). EU on näihin verrattuna vielä suhteellisen pieni toimija (3,0 Mtoe). Suomessa toimii yksi iso kaupallinen tuotantolaitos (Neste Oil Oyj:n ensimmäinen NExBTL-laitos Kilpilahdessa, joka käynnistyi kesällä 2007; toinen samanlainen laitos on rakenteilla niin ikään Kilpilahteen) sekä muutamia pienempiä kaupallisia laitoksia, jotka tuottavat bioetanolia (St1 Biofuels Oy), biodieseliä (rasvaestereitä) tai biometaania.

Tuotantokapasiteetin lisärakentamiseen on maailmanlaajuisesti monia kannustimia. Euroopassa kehitystä ohjaa vuonna 2003 asetettu "biopolttoainedirektiivi" (2003/30/EC). Suomessa astuu vuonna 2008 voimaan em. direktiivin ohjaamana niin kutsuttu käyttövelvoitelaki. Se määrää, että Suomessa myytävistä tieliikenteen polttoaineista on oltava asteittain suureneva osuus biopolttoaineita siten että vuonna 2010 biopolttoaineiden osuus polttoainemyynnistä vastaisi 5,75 energiaprosenttia. Eurooppa-neuvoston keväällä 2007 julkaiseman energiapaketin puitteissa asetettiin uusi tavoite, joka määrää, että biopolttoaineosuuden tulisi vuoteen 2020 mennessä nousta jo 10 energiaprosenttiin. Etanolin uskotaan säilyvän tärkeimpänä globaalina tieliikennebiopolttoaineena ainakin vuoteen 2015 saakka.

Etanolia voidaan tuottaa eri tavoin. Eri vaihtoehdoista teollisesti kaikkein suosituin on sokeriin perustuva käymisreitti. Globaalisti merkittävimmät teolliset sokerilähteet nykyisille bioetanolitehtaille ovat sokeriruoko ja -juurikas, maissi, vilja sekä muutamat muut tärkkelyspitoiset maataloustuotteet (nk. ensimmäinen sukupolvi). Sakkaroosista (sokeriruoko ja -juurikas) sekä tärkkelyksestä alkavien tuotantoprosessien ohella bioetanolia voidaan tuottaa myös selluloosasta (nk. toisen sukupolven bioetanoli). Luonnossa selluloosaa ei löydy suuria määriä sellaisenaan (puhtaana), vaan tyypillinen massatuotantoon sopiva selluloosarikas materiaali sisältää myös merkittäviä määriä hemiselluloosaa, ligniiniä ja erilaisia mineraaleja. Tästä johtuu termi lignoselluloosa. Toisen sukupolven tuotantoreitti on teknisesti ensimmäisen sukupolven reittiä huomattavasti haastavampi, koska raaka-aineen käymiskelpoiset sokerit ovat raaka-aineesta vaikeammin erotettavissa kuin esim. tärkkelyksestä. Potentiaalisia raaka-ainelähteitä toisen sukupolven tuotannolle ovat erilaiset korjuutähteet ja runsaasti lignoselluloosaa sisältävät teollisuuden prosessointisivuvirrat, puubiomassa sekä energiakasvit.

Kaupallisia toisen sukupolven tuotantolaitoksia on jo maailmalla muutamia toiminnassa. Venäjällä toimi ainakin vielä 1990-luvun lopulla tämäntyyppisiä laitoksia. Myös Ruotsissa sijaitsevaan sulfiittimassatehtaaseen integroitu etanolitehdas (Domsjö Fabriker, Örnsköldsvik) voidaan luokitella kaupalliseksi toisen sukupolven laitokseksi. Uusia toisen sukupolven teollisen mittakaavan tuotantolaitoksia rakennetaan paraikaa, varsinkin Yhdysvalloissa. Ensimmäisten uusien laitosten uskotaan olevan toiminnassa aikaisintaan ensi vuonna.

Tässä esitetyt tulokset tehtiin osana VTT:n ja MTT:n yhteistä hanketta, jossa tarkasteltiin etanolin valmistamista kotimaisista maatalouden selluloosarikkaista materiaalivirroista, lähinnä viljan oljesta ja energiakas vina tunnetusta ruokohelvestä. Oljen potentiaali on kotimaisista maatalouden korsibiomassoista selkeästi suurin. Ruokohelpi on vastaavasti mielenkiintoisimpia Suomessa kasvatettavia energiakasveja. Tässä paperissa käydään läpi prosessin teknisiä näkökantoja ja esitetään konseptista tehdyt alustavat kannattavuuslaskelmat. Projektia rahoittivat Tekesin ClimBus-teknologiaohjelma, VTT, MTT sekä viisi kotimaista yritystä. Projektiin osallistui suuri joukko tutkijoita MTT:ltä ja VTT:ltä. Lisätietoja projektista on saatavilla aihetta käsittelevästä tiedotteesta (VTT Tiedotteita 2412, 2007).

\section{Aineisto ja menetelmät}

Raaka-aineen konversiota etanoliksi tutkittiin VTT:n laboratoriossa. Osa höyryräjäytyskokeista tilattiin alihankintana joko Lundin yliopistosta Ruotsista tai KCL:Itä. MTT:Itä saadut raaka-ainenäytteet silputtiin ja käsiteltiin happokatalyytillä esikäsittelyn tehostamiseksi. Esikäsittelyn olosuhteet vaihtelivat hieman suorituspaikkojen mukaan. Lundissa kokeet tehtiin höyryräjäytykseen suunnitellussa koelaitteistossa. Seulomattomattoman raaka-aineen happamuus laskettiin lisäämällä siihen rikkidioksidia. Ylälämpötila oli 190 
${ }^{\circ} \mathrm{C}$ ja viipymäaika ylälämpötilassa 5 min. KCL:llä höyryräjäytyksiin käytettiin kymmenen litran reaktoria, jossa oli tarkoitukseen sopiva poistoventtiili ja sykloni tuotteen talteenottoon. Silputun ja seulotun $(2 \mathrm{~mm}$ seulakoko) materiaalin happamuus laskettiin rikkihapolla, ja ylälämpötilat olivat $190-206{ }^{\circ} \mathrm{C}$. Hypoteettiseen tehtaaseen valittiin seuraavat olosuhteet: hapotus rikkihapolla siten, että rikkihapon alkukonsentraatio oli 0,25 massaprosenttia, ja viipymäaika ylälämpötilassa $200^{\circ} \mathrm{C}$ viisi minuuttia.

Entsymaattiseen hydrolyysiin testattiin useita kaupallisia entsyymejä. Tehokas hydrolysoituminen edellyttää sekä sellulaasivalmisteen että mahdollisesti $\beta$-glukosidaasivalmisteen lisäämistä. Sellulaaseista testattiin seuraavat: Econase ${ }^{\circledR}$ (AB Enzymes), Spezyme ${ }^{\circledR} \mathrm{CP}$ (Genencor) ja Celluclast ${ }^{\circledR} 1.5 \mathrm{~L}$ (Novozymes). $\beta$ Glukosidaasivalmiste oli Novozym 188 (Novozymes). Sellulaasien tehokkuudessa ei ollut suuria eroja. Hypoteettisessa tehtaassa käytettiin entsyymiannostusta $10 \mathrm{FPU}$ sellulaasia / g kuivaa raaka-ainetta ja 100 nkat Novozym 188-valmistetta / g kuivaa raaka-ainetta. Lämpötila ja happamuus oli säädetty arvoihin $45^{\circ} \mathrm{C}$ ja pH 5. Entsymaattisen hydrolyysin alussa kuiva-ainepitoisuus oli säädetty 15 massaprosenttiin.

Noin kolmen tunnin esihydrolyysin jälkeen materiaali siirrettiin bioreaktoriin (fermentoriin), jossa sen lämpötila säädettiin $32{ }^{\circ} \mathrm{C}$ :seen. Joukkoon lisättiin hiivasolut (VTT:n oma hiivakanta, joka ainakin puhtailla sokereilla kasvaessaan tuottaa myös viisihiilisistä sokereista etanolia). Käymisen (fermentoinnin) aikana happamuutta ei säädetty. Sopivaksi käymisajaksi hypoteettisessa tehtaassa arvioitiin 70 tuntia.

Käymisen jälkeen kiintoaine erotettiin suodattamalla ja sen lämpöarvo arvioitiin soveltaen seuraavia standardimenetelmiä: DIN 51718, DIN 51720, CEN 335 ja DIN 51900.

Aine- ja energiataseet laskettiin VTT:1lä kehitetyllä kaupallisella Balas-prosessisimulointiohjelmistolla (balas.vtt.fi). Investointi- ja käyttökustannuslaskelmat tehtiin taseiden pohjalta Microsoftin Excelillä.

\section{Tulokset ja tulosten tarkastelu}

Suomessa on $50 \mathrm{~km}$ keskikuljetusetäisyydellä valitusta tehdaspaikasta parhaimmillaan saatavilla noin 160000 tonnia raaka-ainetta (kuiva-paino). Tämä voi olla pelkästään olkea tai sekä olkea ja ruokohelpeä. Raakaaineen hinnaksi tehtaan portilla arvioitiin $52,3 € / \mathrm{t}_{\mathrm{ka}}$. (katso Johdannossa mainittu tiedote).

Lignoselluloosamateriaalin konvertointi etanoliksi voidaan toteuttaa eri tuotantokonsepteja (prosessikokonaisuuksia) soveltamalla. Käymisprosessia soveltavat konseptit koostuvat tyypillisesti seuraavista päävaiheista:

- materiaalin paloittelu, pilkkominen tai jauhatus (esim. hakkeeksi, silpuksi tai jauheeksi)

- selluloosan ja hemiselluloosan pilkkominen sokereiksi

- sokereiden konvertointi etanoliksi (eli käyminen)

- etanolin erotus muusta materiaalista ja sen viimeistely myyntiä varten.

Erilaisia uusia teknologioita ja konsepteja kehitetään jatkuvasti. Valitsimme tähän työhön prosessikokonaisuuden, jonka teknologiat (osaprosessit) edustavat nykyistä parasta osaamistasoa ja riittävää teknologista kypsyyttä globaalissa perspektiivissä. Valitut teknologiat ovat siis olemassa (sovellettavissa), mutta joitakin niistä on testattu vasta laajamittaista tuotantoa pienemmässä mittakaavassa (koetehdas), joten niiden teknologiseen kypsyyteen liittyy avoimia kysymyksiä. VTT:n laboratoriossa voitiin kuitenkin käytännössä testata valittujen teknologioiden toimivuutta tämän projektin raaka-aineilla ja näin tuottaa tietoa alustavien kannattavuuslaskelmien tekoon.

Prosessissa syntyvät sivuvirrat on myös huomioitava. Merkittävä osa alkuperäisestä raaka-aineesta päätyy nimittäin näihin. Valitsemassamme konseptissa suurin osa sivuvirroista muutetaan energiaksi, josta suurin osa palautuu etanolitehtaan käyttöön. Vaikka näin toimiva etanolitehdas on omavarainen energian suhteen, voidaan katsoa tällaisen konseptin tuottavan oljesta ja/tai ruokohelvestä kahta päätuotetta: etanolia ja energiaa (sähkön ja lämmön muodossa).

Valitut osaprosessit ja päämassavirrat esitetään kuvassa 1. Tehtaan vuotuinen raaka-ainetarve on 160000 tonnia (kuivapaino). Tästä saadaan laboratoriotulosten perustella noin 31000 t puhdasta $(99,8$ massaprosenttia) etanolia. Saanto raaka-aineesta olisi tällöin noin 19 massaprosenttia. Energiatase ja sivuvirtojen sovelluskohteita on käsitelty tiedotteessa VTT Tiedotteita 2412. 


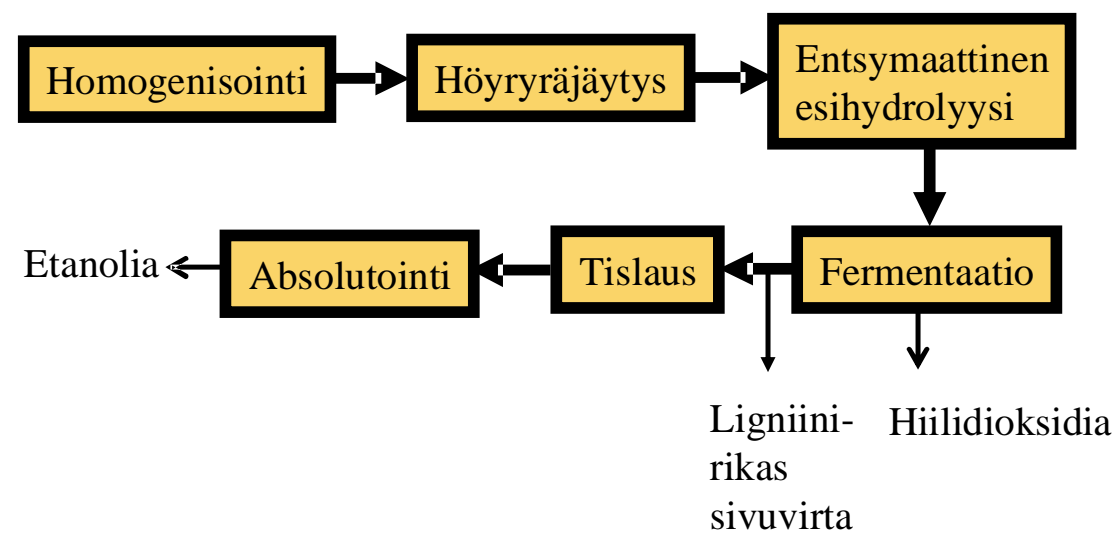

Kuva 1. Pelkistetty kaavakuva selluloosa-etanolitehtaasta.

Massataseen pohjalta suunniteltiin eri laitteiden koko. Laitoksen investointi on taulukon 1 mukainen. Taulukossa investointikustannukset on jaettu prosessin eri osastoille. Kohta "muut" koostuu prosessilaitteista, joita ei mitoitettu, sekä etanolin varastosäiliöistä. Menot sisältävät laitekustannukset sekä niiden asennuksen ja tarvittavien rakennuksien rakennuskulut. Suurin epävarmuus investoinneissa on laitoksen osissa, joita ei ole mitoitettu ja laskettu tarkemmin. Niitä ovat haihduttamo, energian-, entsyymien- ja hiivantuotanto. Laskennan epätarkkuus on lopuksi huomioitu varauksessa, joka on $20 \%$.

Taulukko 1. Hypoteettisen selluloosa-etanolitehtaan investointimenot.

\begin{tabular}{|r|c|}
\hline Osasto & Laitekustannus (1000 $€$ ) \\
\hline Höyryräjäytys & 3600 \\
\hline Hydrolyysi & 2780 \\
\hline Fermentointi & 7300 \\
\hline Kiintoaineen erotus & 10200 \\
\hline Tislaus \& absolutointi & 5600 \\
\hline Haihdutus & 14000 \\
\hline Energian tuotanto & 20000 \\
\hline Hntsyymin tuotanto & 10000 \\
\hline Hiivan kasvatus & 9800 \\
\hline muut & 8500 \\
\hline & \\
\hline Yhteensä (k€) & 92000 \\
\hline Varaus (\%) & $20 \%$ \\
\hline Investointikustannus (k€) & 110000 \\
\hline
\end{tabular}

Tuotantokulut esitetään taulukossa 2.

Taulukko 2. Hypoteettisen selluloosa-etanolitehtaan tuotantokulut.

\begin{tabular}{|r|c|l|c|c|c|}
\hline & Hinta & Yksikkö & Kustannus 1000 €/vuosi & $\boldsymbol{\epsilon} /$ etanolia & $\%$ \\
\hline olki & 52.5 & $€ /$ dry & 8400 & 0.22 & 39 \\
\hline sähkö & 45 & $€ / \mathrm{MWh}$ & 1126 & 0.03 & 5 \\
\hline prosessivesi & 0.8 & $€ / \mathrm{t}$ & 324 & 0.01 & 2 \\
\hline jäähdytysvesi & 0.03 & $€ / \mathrm{t}$ & 406 & 0.01 & 2 \\
\hline jätevesi & 1.4 & $€ / \mathrm{t}$ & 1005 & 0.03 & 5 \\
\hline Muut & 35.58 & $€ /$ t etanolia & 7689 & 0.20 & 36 \\
\hline & & & 1094 & 0.03 & 5 \\
\hline Muuttuvat kustannukset & & & 20000 & & \\
\hline Kiinteät kustannukset & & & 1400 & 0.51 & 93 \\
\hline Käyttökustannukset & & & 21400 & 0.04 & 7 \\
\hline
\end{tabular}

Merkittävin kustannustekijä on raaka-aine, joka vastaa noin $39 \%$ :a kaikista tuotantokuluista. Myös entsyymeihin liittyvät kustannukset ovat merkittävät (noin $36 \%$ ). Perustapauksemme mukaan suoriksi tuotantokuluiksi muodostuisi arviolta noin $0,55 € /$ litra etanolia. Usein tuotantokuluihin lisätään myös 
investointiin liittyvien kulujen merkitys. Tämä merkitys arvioitiin kertomalla investointimenot (110 miljoona euroa) valitulla annuiteettikertoimella (10 v ja $10 \%)$, jolloin laskettiin investointimenon vuotuiseksi arvoksi noin 18 miljoonaa euroa. Tästä saatiin investointimenon kustannustekijä $0,46 € /$ litra etanolia. Yhteenlasketut tuotantokustannukset ovat siis noin $1 € /$ litra.

Tarkemmat kannattavuuslaskelmat löytyvät tiedotteesta VTT Tiedotteita 2412. Kannattavuuden kannalta keskeisemmät muuttujat olivat: pääraaka-aineen hinta, entsyymeihin liittyvät kustannukset, etanolin saanto raaka-aineesta, etanolin myyntihinta sekä mahdolliset investointituet.

\section{Johtopäätökset}

Tässä tiedotteessa raportoidaan tuloksia kahdesta tutkimusprojektista. Projektien taustaksi suunniteltiin hypoteettinen tehdas, jossa 160000 tonnista olkea tai olkea ja ruokohelpeä tuotettaisiin noin 31000 tonnia etanolia. Tämäntyyppisen prosessikonseptin kuten monen muunkin biomassaa käyttävän tehtaan kokoa rajaa raaka-aineen saatavuus tehtaan läheisyydessä. Suomen oloissa valitsemamme kokoluokka edustaa suurin piirtein vallitsevaa ylärajaa tehtaalle, joka korsibiomassasta valmistaisi etanolia. Valittua tehdasmallia soveltaen tehtiin alustavia arvioita tuotannon teknisestä kypsyydestä, investoinnin kannattavuudesta sekä tuotannon ilmastovaikutuksista. Arvio tehtiin sitä taustaa vasten, että tehdas sijoittuisi Suomeen ja soveltaisi kotimaisia raaka-aineita. Tuotantoketjun vahvuudet, heikkoudet, riskit ja mahdollisuudet on koottu oheisen yhteenvetoon.

- Teknologia etanolin valmistamiseksi korsibiomassoista on olemassa, joskin eri prosessivaiheiden optimointia tarvitaan ja teknologian kehitystarve on merkittävä

- Bioetanolille on kysyntää Euroopassa, todennäköisesti myös Suomessa.

- Tuotanto loisi uuden maataloudesta alkavan jalostusketjun häiritsemättä elintarvikesektorin jalostusketjuja.

- Suunnitellun tehtaan tuotanto alentaisi hieman Suomen öljyriippuvuutta, koska tuotettu bioetanoli korvaisi öljypohjaisen bensiinin käyttöä. Vaikutus olisi tosin hyvin pieni (vähentäisi bensiinin käyttöä noin prosentin).

- Bensiinin korvaaminen olki- tai ruokohelpietanolilla vähentäisi myös hyvin todennäköisesti kasvihuonekaasupäästöjä merkittävästi suhteessa korvattuun polttoainemäärään.

Heikkouksia:

- Huolimatta siitä, että raaka-aineita on saatavilla Suomessa (tai niiden tuotantoa voitaisiin lisätä ruokohelven tapauksessa), ei materiaalia ole järkevällä säteellä riittävästi isomman tehtaan pyörittämiseen (hypoteettisen tehtaamme laitoskoko piti siis rajata 160000 tonniin raaka-ainetta/ vuosi).

- Kaikkien tarvittavien teknologioiden toimivuutta täydessä teollisessa mittakaavassa ei vielä ole osoitettu.

- Käyttämillämme oletusarvoilla normaalissa markkinataloudessa (ts. tilanteessa ilman mahdollisia investointitukia tai tuotantokuluihin ja lopputuotteen hintaan vaikuttavia tukitoimia) investointi ei olisi kannattava, koska

o tuotantolaitoksen investointimenot ovat suhteellisen suuret ("kaksinkertaiset" verrattuna suurin piirtein samansuuruiseen jyvä-etanolitehtaaseen), ja

○ vaikka laitos käyttäisi halvempaa raaka-ainetta (verrattuna esim. vehnän ja ohran jyviin), niin muut suorat tuotantokulut ovat vielä jyvä-etanolireitin kuluja selvästi suuremmat.

Mahdollisuuksia:

- Teknologioita voidaan vielä parantaa. Niihin liittyvä maailmanlaajuinen kehitystyö on tällä hetkellä ekstensiivistä.

- Tehtaassa valmistetusta sokeriliemestä ja muista raaka-ainefraktioista (esim. ligniini) voidaan tulevaisuudessa tehdä myös muita tuotteita, joiden arvo on etanolin tai energian 
Riskejä:

arvoa korkeampi tai joiden tuottama liikevaihto toisi tarvittavan lisän investoinnin kannattavuuslaskelmiin. Nyt suurin sivuvirta menee energian tuottoon, mikä on alhaisen jalostusarvon ratkaisu.

- Etanolin kysyntä voi laskea poliittisten ja verotuksellisten syiden takia.

- Kasvava öljyn hinta ja biomassan muun käytön lisääntyminen (esim. muun bioenergian tuotanto) voivat nostaa raaka-aineen hintaa entisestään.

Bioetanolin valmistus lignoselluloosaraaka-aineista on jo tänä päivänä todellisuutta. Asetettujen kovien biopolttoainetavoitteiden ja niiden tueksi allokoitujen tutkimusrahojen siivittäminä tulee selluloosaetanolituotantoketjun perustuva globaali liiketoiminta kasvamaan merkittävästi lähivuosina. Ratkaisumalleja tulee maailmanlaajuisesti olemaan monia (monia raaka-ainelähteitä, erilaisia prosessikonsepteja, integrointimahdollisuudet muuhun teollisuuteen, jne.). Keskeisiä kysymyksiä ovat:

- Raaka-aineen riittävyys ja saatavuus riittävän alhaiseen hintaan.

- Uudet tuotantokonseptit ja kehittyvät teknologiat, jotka merkittävällä tavalla vähentävät investointimenoja ja tuotantokuluja.

- Mahdolliset muut tuotteet, joita voidaan valmistaa samasta raaka-aineesta hyödyntämällä prosessin sivuvirtoja (esim. ligniinistä ennen polttoa).

- Tuotantoketjun (well-to-wheel) ympäristövaikutusten huomioiminen kehitystyössä.

\section{Kirjallisuus}

Anonyymi. 2006. World Energy Outlook 2006. International Energy Agency, OECD/IEA, p. 385-387. 